\title{
Vypracovanie domácich úloh v poškolských zariadeniach $v$ premenách času ${ }^{1}$
}

\author{
Zuzana Bánovčanová, Michaela Bieliková
}

Trnavská univerzita v Trnave, Pedagogická fakulta

\begin{abstract}
Abstrakt: Školské kluby detí (ŠKD) sú výchovno-vzdelávacím zariadením, v ktorom deti trávia (vol'ný) čas, kým sú ich rodičia v práci a nemôžu sa im venovat', často ani pomáhat' s domácimi úlohami (DÚ). Príspevok sa zameriava na ŠKD v oblasti prípravy na vyučovanie a písania si DÚ. Tie tvoria súčast' výchovno-vzdelávacej činnosti týchto zariadení už od vzniku prvých opatrovní (útulkov) na našom území. Orientuje sa aj na ozrejmenie funkcií vol'ného času a poškolských zariadení, ktoré sa v jednotlivých zariadeniach a obdobiach menili vzhl'adom na samotnú prípravu na vyučovanie. Príspevok prináša periodizáciu spôsobu realizácie Dú vzhladom na dominantné postavenie jednotlivých funkcií v týchto zariadeniach. Spôsoby realizácie prípravy na vyučovanie v jednotlivých obdobiach čerpá príspevok priamo z dostupných dobových príručiek a dokumentov pre vychovávatel'ky. Z nich vyplýva, že do popredia vystupuje $v$ každom období najmä sociálna funkcia, ktorej obsah a zámer sa menia vzhl'adom na ideológiu a politiku štátu.
\end{abstract}

Klúčové slová: domáce úlohy, poškolské zariadenia, príprava na vyučovanie, školský klub detí

\section{Homework in Afterschool Programs and Its Transformations Over Time}

Abstract: Children's after school clubs (ChASC) are educational facilities where children spend (leisure) time when their parents are at work. From this reason, parents cannot take care of their children and help them with their homework. The contribution focuses on the ChASC in the field of schooling preparation and homework writing which is a part of the educational activities of these facilities since the formation of first caretakers (shelters) in our territory. It also focuses on the clarification of functions of leisure time and after school programs, which have changed in individual facilities and periods with regard to schooling preparation itself. The contribution brings the periodicity of the way of implementation homework considering the dominant position of each function in these facilities. Methods of realization of schooling preparation in individual periods obtain a contribution directly from the available periodic handbooks and documents for educators. It follows that the social function, whose content and intent changes with respect to the ideology and the state policy, is at the forefront.

Keywords: homework, after school programs, schooling preparation, children's after school club

Na viacerých miestach sa stretávame s diskusiami (odbornými i laickými) o školskej úspešnosti našich detí, žiakov. Diskutuje sa o tom, prečo nie sú slovenskí žiaci takí dobrí v prírodovedných predmetoch, prečo majú medzery v čítaní s porozumením a pod. V takejto diskusii máme zainteresovaných množstvo ludí s množstvom názorov, no niekedy sa stretneme aj s návrhom riešenia. Diskusia však prebieha najmä zo strany odborníkov a učitel'ov a zo strany rodičov. Určitým činitel'om v tejto diskusii sú však aj výchovno-vzdelávacie zariadenia, najmä školské kluby detí, ktoré tu zostávajú bokom. Nechceme ponúkat' riešenie ani návrhy, poukazujeme na školské kluby

1 Príspevok je výstupom projektu VEGA č. 1/0258/18 Školská politika v efektoch a dôsledkoch prípadové štúdie organizácií formálneho vzdelávania. 
30 detí (d’alej ŠKD) ako miesto, ktoré so školskou úspešnost’ou našich žiakov súvisí. ŠKD je „prechodom“ žiaka zo školského prostredia do vol’nočasového. ${ }^{2}$ Jednou z výchovno-vzdelávacích činností realizovaných v ŠKD je práve príprava na vyučovanie, ktorej sa bude tento príspevok venovat'.

V zahraničnej literatúre sa stretávame s rôznymi funkciami, ktoré zabezpečujú programy ${ }^{3}$ fungujúce $v$ poškolských zariadeniach. Jednou $z$ nich je rozvíjanie alebo zlepšovanie školských zručností, a tým aj školskej úspešnosti diet'at'a, ktorá súvisí so zámerom nášho príspevku. Podla Cosden et al. (2001) majú túto funkciu mnohé poškolské zariadenia, avšak rozdiel je $v$ tom, aké aktivity a v akom časovom rozpätí det’om poskytujú. Zamerali sa na dva typy programov, ktoré tieto poškolské zariadenia ponúkajú, a ktoré pomáhajú det'om s domácimi úlohami (DÚ). Sú to programy: (a) ktoré pomáhajú s DÚ v nadväznosti na školské kurikulum, a, (b) ktoré pomáhajú zlepšit' školské zručnosti a skúsenosti bez nadväznosti na školské kurikulum. Označili ich ako programy, ktoré ponúkajú akademickú podporu a programy, ktoré ponúkajú podporu pri vypracovaní Dú.

Programy, ktoré ponúkajú akademickú podporu, poskytujú všeobecnú akademickú podporu, ktorá nesúvisí s konkrétnym školským kurikulom. Sú to rôzne programy, ktoré sa napríklad zameriavajú na čitatel'ské zručnosti, výslovnost' a porozumenie textu, najmä u detí zo znevýhodnených rodín či minoritných skupín. Programy, ktoré ponúkajú podporu pri vypracovaní domácich úloh opisujú ako programy, ktoré ponúkajú det’om asistenciu pri vypracovaní Dú. Tak deti dostávajú asistenta, ktorý im interpretuje a ozrejmuje napr. zadania Dú, dohliada na systematické vypracovanie a pod. (Cosden et al., 2001, 2004). Môžeme povedat', že nášmu prostrediu, respektíve problematike písania DÚ $\vee$ ŠKD, zodpovedá práve tento druhý typ programu $\checkmark$ poškolských zariadeniach. Beck (1999) vykonal v USA kvalitatívnu evaluáciu týchto programov, ktoré poskytovali det’om od materskej školy po 12. ročník 45 minútové činnosti, ktoré možno obsahom činnosti prirovnat' k príprave na vyučovanie v ŠKD. Autor sa zameral na dížku týchto činností, štruktúru a vyučovaciu podporu pre žiakov. Zistil, že poškolské programy, ktoré sa zameriavajú na školskú úspešnost' žiakov, môžu vplývat' na sebadôveru detí a ich status v školskom prostredí. To znamená, že žiaci, ktorí sa zúčastňovali tohto programu, mali väčšiu istotu v dosahovaní školských výsledkov v škole. Aj Cho a Huang (2009) uvádzajú, že tieto poškolské programy poskytujú žiakom optimálne prostredie a podporu na dokončenie Dú. To následne vedie k tomu, že žiaci dosahujú aj úspech v učení. Rovnako aj učitelia vnímajú pozitívne snahu žiakov pri učení. $V$ porovnaní s anglicky hovoriacimi krajinami (Minárechová \& Bánovčanová, 2016) sa u nás takto špecificky orientované poškolské programy vyskytujú ojedinele a nie sú celoplošne podporované a aplikované štátom vo všetkých ŠKD. Na rozdiel od nášho prostredia ${ }^{4}$ sú tieto programy $v$ zahraničí rodičmi vyberané

2 Prechod medzi školským a vol'nočasovým prostredím vnímame z priestorového a časového hladiska, kedy tieto zariadenia tvoria medzičlánok medzi pobytom diet'at'a v škole a doma.

3 V príspevku rozlišujeme pojem poškolský program a zariadenie. Pod pojmom program rozumieme určité cielené zameranie konkrétnej režimovej činnosti v poškolskom zariadení.

4 Ak nie je uvedené inak, naším prostredím myslíme Slovensko. 
cielene, resp. samosprávy ich cielene zriad'ujú v určitých komunitách alebo sú zriad'ované súkromným sektorom. U nás sa teda s takýmto konkrétnym typom poškolských programov stretneme len ojedinele, avšak najdostupnejšia a najrozšírenejšia alternatíva poškolského zariadenia, ktorá sa venuje aj príprave na vyučovanie, je ŠKD. Preto je naším hlavným ciel'om opísat', ako sa vypracovávanie Dú v poškolských zariadeniach menilo od počiatkov vzniku opatrovní (útulkov), cez družiny mládeže a školské družiny, až po dnešné školské kluby detí. Ciel'om je aj priblížit' jednotlivé funkcie ŠKD cez prizmu prípravy na vyučovanie a písania si DÚ. Tieto funkcie sa s ohladom na obdobie a konkrétne zariadenie menili, preto sa funkcie volného času (takto uvádzané v česko-slovenskej literatúre) a funkcie poškolských zariadení (uvádzané v zahraničnej literatúre) prelínajú celým textom. Týmto spôsobom chceme poukázat' na to, že Dú sa spájajú s týmito zariadeniami od ich vzniku, pričom v línii času dochádza k preusporiadaniu týchto funkcií z hladiska prípravy na vyučovanie. Nadväzujúc tak na úvodnú tému školskej úspešnosti našich detí a súčasného pracovného vyt'aženia rodičov, prispejeme do spomenutej diskusie d'alšou mierne opomínanou témou $v$ našom pedagogickom prostredí.

Výstupom tejto štúdie je návrh typológie prístupov k vypracovaniu domácich úloh $v$ poškolských zariadeniach $v$ premenách času, s ohl'adom na ciele, obsah, metódy i časovú dotáciu prípravy na vyučovanie.

\section{Funkcie poškolských zariadení a funkcie vol'ného času}

Otázka vyššie načrtnutej školskej úspešnosti našich detí/žiakov sa dotýka aj ŠKD, a to priamo $v$ súvislosti so spomínanou výchovno-vzdelávacou činnost'ou prípravy na vyučovanie. Bez akéhokolvek zastierania ju mnohí stotožňujú s vypracovaním si domácich úloh. Podla Cosden et al. (2001) má vypracovanie DÚ rôzne funkcie, od drilu, nacvičovania zručností, po rozšírenie či doplnenie preberaného učiva. Rovnako slúži Dú aj rodičom, aby vedeli, čo sa v škole preberá, čomu sa ich diet'a venuje $\checkmark$ školskom čase. $V$ neposlednom rade je DÚ aj nástrojom trestania žiaka učitelom. Pedagógovia či psychológovia majú rôzne, ak nie rozdielne názory na to, či je Dú pre diet’a prospešná, či a kedy má Dú význam. ${ }^{5}$ V našom príspevku nám nejde o to, či má DÚ význam, alebo či je povinná. Chceme poukázat' na to, že Dú sú súčast'ou života každého diet'at'a, a tým aj jeho rodiča/rodičov. ŠKD navštevuje množstvo detí, ktorých rodičia pracujú a je to zariadenie, ktoré pomáha najmä vyplnit' čas od skončenia vyučovania po návrat rodiča z práce. Tento čas strávený v ŠKD je plánovaný a organizovaný, diet'a je pod dozorom vychovávatela. Diet'a tu trávi svoj vol'ný čas produktívnym a aktívnym spôsobom. Tento čas tak vytvára aj priestor na prípravu

5 O význame Dú pre diet’a sa verejne diskutuje aj na sociálnych siet’ach a rôznych fórach. Najmä $\checkmark$ poslednej dobe $v$ Českej republike sa danou témou média zaoberali po zverejnení informácie o blogu otca, ktorý presvedčil riaditela školy o tom, že Dú nie sú povinné. 
32 diet’at’a na nasledujúci školský deň, teda na vypracovanie si DÚ alebo na opakovanie a učenie sa učiva.

Prostredie ŠKD či v zahraničí spomínaných rôznych poškolských programov je prepojené s poskytovaním/zabezpečovaním rôznych funkcií, ktoré sa bezprostredne viažu $k$ tomuto špecifickému prostrediu, a to prostrediu usporiadanému v rozmedzí času medzi klasickým vyučovaním a pobytom diet’at’a doma. $\mathrm{V}$ nasledujúcom texte predostrieme tieto funkcie, s ktorými sa jednak stretávame $v$ prácach českých a slovenských autorov (Hájek, Hofbauer, \& Pávková, 2008; Kratochvílová, 2010; Pávková et al., 2008), ale aj zahraničných autorov (napr. Cosden et al., 2001; Johnston, 2011; Johnson \& McComb, 2008; Mahoney, Parente, \& Zigler, 2009). Považujeme za dôležité ich stručné objasnenie vzhladom na postavenie režimovej činnosti prípravy na vyučovanie a s ňou spojené DÚ v našom prostredí.

Už vyššie spomínaní autori, Cosden et al. (2001), sa vyjadrujú o funkciách poškolských zariadení (afterschool programs) pre deti, ktoré sú v niektorých štátoch USA organizačne vel'mi podobné našim ŠKD (napr. štát Michigan, pozri bližšie Minárechová \& Bánovčanová, 2016). Jednou z funkcií takýchto programov je aj zlepšenie školskej úspešnosti diet'at'a. Medzi hlavné funkcie autori zarad'ujú: (a) bezpečie a dohlad; (b) kultúrnu a komunitnú identifikáciu; (c) rozvoj sociálnych zručností; (d) zlepšenie školskej úspešnosti.

Dohl'ad a bezpečie sú základnými komponentmi väčšiny takýchto programov. Mnohé štúdie (Adams, Tout, \& Zaslow, 2007; Beck, 1999; Halpern, 1992; Mullan, 2012; Posner \& Vandell, 1999; Sarampote, Bassett, \& Winsler, 2004) už písali o tom, že deti často trávia aj určitý čas po skončení vyučovania bez dohladu dospelej osoby. Prevažne sa tieto štúdie vyjadrujú o tom, že je tu zvýšené riziko antisociálneho správania sa detí, ktoré nie sú pod dozorom dospelej osoby a trávia čas samé, unudené, alebo $v$ spoločnosti rovesníkov niekde vonku.

Rozvoj sociálnych zručností v poškolských programoch je založený na tom, že diet’at'u je poskytované prostredie, v ktorom interaguje $s$ inými det'mi, ale aj dospelými (Cosden et al., 2001). Čiastočne to súvisí aj s prvou opisovanou funkciou, pretože diet’a je pod dohl'adom dospelej osoby, ktorá má na neho vplyv, pôsobí ako sociálny vzor. Je to dôležité najmä u detí, ktoré by po skončení vyučovania neboli pod dozorom dospelej osoby, trávili by čas samé alebo so súrodencom, či s inými rovesníkmi. Vzt’ahujúc túto funkciu na naše kultúrne prostredie a ŠKD by sme mohli hovorit' o socializačnej funkcii vol'ného času (Kratochvílová, 2010). Ako sme už čiastočne načrtli, Kratochvílová (2010) písala o funkciách volného času (Cosden et al., 2001, o funkciách poškolských zariadení), nie však o funkciách ŠKD. Preto by táto funkcia v jej ponímaní bola oklieštená len na prostredie ŠKD, kde ide najmä o rozvoj vzt'ahov medzi rovesníkmi a vychovávatelom.

Súčasní českí (Hájek et al., 2008; Pávková et al., 2008) a slovenská autorka (Kratochvílová, 2010) tak hovoria o funkciách volného času, ktoré sú spájané s rozličnými poškolskými zariadeniami. Je zaujímavé sa na jednej strane pozriet' na vývoj poškolských zariadení, ktoré primárne súvisia s vol’ným časom detí, no na druhej strane sú vypracovávanie DÚ a príprava na vyučovanie spájané s povinnost’ou. Preto sme sa 
zamerali na oblast' DÚ v poškolských zariadeniach cez prizmu funkcií vol'ného času,

aj s ohladom na ich historický vývoj. Otázkou je, prečo sú, resp. boli Dú súčast'ou vol'ného času detí? To nás viedlo $\mathrm{k}$ hl'adaniu podobnej problematiky $v$ zahraničnej literatúre, ale najmä k pátraniu po domácich zdrojoch, ktoré by nám ozrejmili kedy, ako a prečo boli DÚ do poškolských zariadení zavádzané. Ak vychádzame z názvu „domáca úloha“, predpokladáme, že je primárne spájaná s domácim (rodinným) prostredím. Nasledujúci text však poukazuje na to, že domáca úloha nebola vždy „domáca“.

\section{Ked’ domáca úloha nie je „domáca“}

Domáca úloha u nás nie je až tak diskutovaná téma ako v zahraničí, ${ }^{6}$ napr. v USA, kde existovali i tendencie začiatkom 20-teho storočia, kedy sa det’om DÚ nesmeli zadávat'. Neskôr sa však začalo diskutovat' o jej význame, efektoch v budúcnosti pre školskú úspešnost' žiaka. Zhrnutím niektorých efektov DÚ v rôznych vyučovacích predmetoch sa zaoberali Eren a Henderson (2011), pričom DÚ nepokladajú vo všetkých oblastiach vzdelávania za prínosné (napr. v dejepise a angličtine efekt DÚ na zlepšenie $v$ testoch nepriniesli, naopak v matematike áno). Ale napríklad už Epstein (1988) uviedol niekol'ko dôvodov, prečo by si mali žiaci písat' Dú. Medzi najčastejšie dôvody, prečo učitelia zadávajú DÚ, patrí zvládnutie základných pojmov súvisiacich s preberaným učivom v škole. Autor d'alej uvádza niekol'ko pozitívnych vplyvov písania si DÚ na samotných žiakov, ako napríklad rozvoj vhodných študijných návykov, uvedomenie si toho, že učenie prebieha aj mimo školského prostredia, či podpora celoživotného vzdelávania. Podobné zámery má aj príprava na vyučovanie ako výchovno-vzdelávacia činnost' v ŠKD. Písanie si Dú vplýva aj na učebné výsledky žiakov. S tým súvisí dĺžka prípravy na vyučovanie, teda čas, ktorý deti trávia aj písaním si DÚ. Vel'ká štúdia, ktorá sumarizovala výsledky v dížke prípravy na vyučovanie $v$ troch krajinách (Čína, Japonsko a USA) poukazuje na kultúrne rozdiely, ktoré majú vplyv na povahu, dížku a pomoc pri písaní Dú (Chen \& Stevenson, 1989). V našom kultúrnom prostredí nenachádzame obdobné štúdie, písanie DÚ sa všeobecne považuje za súčast' školovania už od príchodu detí do Ž̌ (niekedy sa stretávame s Dú aj v predškolskom veku v materskej škole).

Už z úvodných slov je zrejmé, že zadávanie a vypracovanie DÚ má nielen v našom vzdelávacom systéme svoje opodstatnenie. Existujú aj názory, ktoré považujú Dú za stresujúci činitel' pre deti, ale aj ich rodičov. To sa však odvíja aj od veku detí a ich rodinnej situácie. Podla Cosden et al. (2001) sa prostredníctvom Dú dozvedajú rodičia, čo sa ich deti v škole učia, čo potvrdzujú aj Johnson a McComb (2008). Okrem toho uvádzajú, že písanie DÚ vytvára dôležité spojenie medzi školami a rodinami. Vychádzajúc $z$ toho by sme mohli povedat', že Dú sú prostriedkom, ako vtiahnut' rodiča do vzdelávania ich detí, do spolupráce so školou. Rodič je tak nútený

6 V tomto prípade myslíme diskusiu odbornej verejnosti, pretože vyššie sme $v$ odkaze pod čiarou spomínali diskusiu vyvolanú v médiách na základe blogu českého otca. 
34 v určitých situáciách komunikovat' so školou, najmä s učitelom o povahe a postupoch pri vypracovaní Dú. Cosden et al. (2004) však uvažujú aj o tom, že ak diet’a navštevuje poškolské programy, ktoré ponúkajú asistenciu pri vypracovaní DÚ, tak rodič je z tohto procesu vynechávaný. Podobne je to aj s vypracovaním DÚ v ŠKD. Výchovno-vzdelávacia činnost' prípravy na vyučovanie je zarad'ovaná do denného režimu ŠKD, avšak obsah tejto činnosti nie je presne definovaný. Jednotlivé oddelenia ŠKD, tým aj vychovávatelia, môžu (ale nemusia) s det'mi vypracovávat' DÚ. Tu sa načrtáva otázka komunikácie a spolupráce rodičov s vychovávatel'mi. Väčšinou sa v praxi stretávame s tým, že rodičia sa s vychovávatel'om dohodnú či chcú, aby si ich diet’a v ŠKD vypracovalo DÚ, alebo nie. Ak chcú, vychovávatel' poskytuje det'om asistenciu pri vypracovaní DÚ, niekedy im aj kontroluje správnost' vypracovania. Nie je to však jeho povinnost', ktorá by bola legislatívne ukotvená. Podobne to je aj v českých školních družinách, kde je však legislatívne podchytená možnost' vol'by rodičov o vypracovaní si DÚ (MŠMT ČR, 2002). Takáto asistencia pri vypracovaní DÚ je obzvlášt' žiadaná a vhodná u detí, ktoré nemajú v rodinnom prostredí dostatočné podmienky na vypracovanie Dú (ak má diet’a množstvo súrodencov, nemá osobný priestor, resp. jeho rodič nie je schopný mu poradit' a pod.). Najčastejšie v prvom ročníku si deti DÚ v ŠKD nevpracovávajú, vtedy s nimi v rámci výchovno-vzdelávacej činnosti prípravy na vyučovanie vychovávatel' realizuje rôzne didaktické hry, ktoré slúžia na rozšírenie alebo upevnenie preberaného učiva. Každý ŠKD si vypracováva povinne výchovno-vzdelávací plán, ktorý nadväzuje aj na štátny a školský vzdelávací program, preto majú tieto výchovno-vzdelávacie činnosti nadväznost’ s preberaným učivom.

Rovnako sa o zapojení rodičov do vzdelávania ich detí prostredníctvom DÚ zaoberali aj Walker et al. (2004). DÚ môžu byt' podla nich nástrojom na: (a) umožnenie rodičom a ostatným dospelým, aby vedeli, čo sa diet’a v škole učí; (b) rodičia majú dôvod hovorit' s det'mi o škole; (c) rodičia môžu učitel'ovi poskytnút' informácie o tom, ako sa diet’a doma učí. Ak si však diet’a píše DÚ v ŠKD, preberá túto úlohu vychovávatel'. Výhodou ŠKD je to, že sú zriad'ované pri základnej škole, diet’a tak navštevuje ŠKD $v$ tej istej budove (často aj $v$ tom istom priestore), kam chodí do školy. Preto je aj komunikácia medzi učitelom a vychovávatel'om častejšia a doslova žiadaná. O spolupráci vychovávatel'a s učitelom hovoria aj Johnson a McComb (2008). Tí zdôrazňujú ich spoluprácu z dôvodu rozšírenia obsahu Dú (napr. práca v teréne, projekty, skupinová práca a pod.). Na druhej strane uvádzajú, že aj ked' je vytváranie prepojení medzi školou a poškolským programom často žiadané, väčšina programov má t’ažkosti s dosiahnutím tohto ciel'a $v$ dôsledku rôznych inštitucionálnych kultúr a slabej komunikácie (Noam, Biancarosa, \& Dechausay, 2002). V príspevku d’alej autori uvádzajú aj výhody takejto spolupráce, medzi ktoré zaradili zvýšenú morálku učitel'ov, vyššie hodnotenie učitel'ov rodičmi, lepšiu reputáciu škôl v rámci komunity, lepší výkon poškolských programov. Podla Cosden et al. (2004) je však existencia takýchto programov žiadaná najmä u detí, ktorých rodičia nehovoria anglicky (detí migrantov v USA), a preto je asistencia a pomoc det'om s DÚ zo strany rodičov priam nemožná. 
Vel'mi zaujímavý pohlad na problematiku ponúkajú Corno a Xu (2004). Nesie sa $\checkmark$ duchu metafory, že Dú sú zamestnaním detstva (job of childhood). Hovoria o tom, že DÚ má potenciál rozvíjat' u detí pracovnú etiku a manažérske zručnosti, ktoré sú vysoko cenené zamestnávatelmi. Deti, rovnako ako dospelí zamestnanci musia manažovat' svoj priestor, čas, pozornost' a motiváciu. Musia sa vysporiadat' s prichádzajúcimi t’ažkost’ami, vyrušeniami, sklamaním, nezáujmom, únavou a pod. Aby sa nadobudol tento potenciál DÚ, musia spolupracovat' všetci, ktorí sa na vypracovaní DÚ podiel'ajú: učitelia, deti, rodičia aj vychovávatelia. Preto je príprava na vyučovanie $v$ režime dňa $v$ ŠK zarad'ovaná ako činnost', ktorá deti vedie $\mathrm{k}$ systematickej a pravidelnej príprave na vyučovanie. Deti tak dostávajú možnost' naučit' sa, ako pristupovat' k Dú pod odborným dohl'adom. Podla Cosden et al. (2004) poškolské programy poskytujúce asistenciu pri vypracovaní DÚ okrem iného aj redukujú rodinný stres, rozvíjajú pozitívne postoje ku škole a preberanému učivu a tiež zručnosti detí pri vypracovávaní Dú. Deti vidia aj iné deti, ako si vypracovávajú Dú, čo znamená, že sa posilňuje, ba až zvyšuje potreba školskej úspešnosti u samotného diet'at'a. $\checkmark$ tomto procese nemožno oddelit' dril či zručnost' od sociálneho učenia, ktoré sa $\checkmark$ ŠKD prelínajú a v príprave na vyučovanie dopĺñajú.

\section{Domáce úlohy $v$ poškolských zariadeniach $\checkmark$ premenách času}

V tejto kapitole približime stručný vývoj zariadení, ktoré predchádzali dnešnej podobe ŠKD a postaveniu DÚ v nich. Pri hladaní informácií k historickému prehladu týchto zariadení sme boli značne limitovaní dostupnými zdrojmi, ktoré by sa venovali danej problematike. Ciel'om tohto príspevku nie je poskytnút' historickú analýzu týchto zariadení, ale poukázat' na premeny prípravy na vyučovanie a jej podobu $v$ jednotlivých zariadeniach, s ohl'adom na funkcie vol'ného času a poškolských zariadení. Pre lepšie pochopenie textu je však nevyhnutné podat' aj stručný historický opis a poslanie týchto zariadení. Konkrétne ide o detské útulky, družiny mládeže, školské družiny a školské kluby detí.

Pri opise zariadení a podoby prípravy na vyučovanie sme vychádzali z metodických príručiek ${ }^{7}$ určených pre vychovávatelov vydaných v príslušnom období. Ked’že sa príspevok prioritne nezameriava na opis historických súvislostí a období súvisiacich so vznikom týchto zariadení, ale orientuje sa na spôsob (ne)realizácie Dú v týchto zariadeniach, príručky sme považovali za relevantný zdroj, ktorý poskytuje návod pre vychovávatel'a, ako postupovat' a organizovat' DÚ v rámci prípravy na vyučovanie vzhl'adom na príslušné obdobie a zariadenie, v ktorom pôsobil. Dané príručky sme

7 Tieto metodické príručky (Dedeková et al., 1960; Groch \& Valovič, 1963; Opata, 1980; Podešva, 1952; Špánik, 1990) vychádzali v období transformácie poškolských zariadení a boli venované priamo vychovávatelom. Nenašli sme viac ako jednu príručku pre dané obdobie. $Z$ tohto dôvodu príspevok nereferuje o tom, čo sa $v$ jednotlivých poškolských zariadeniach reálne dialo. Vychádzame z opísaného a odporúčaného stavu, ktorý obsahovali dané príručky. 
36 získali zo Slovenskej pedagogickej knižnice, kde sme narazili na problém s limitovaným počtom odbornej literatúry $v$ danej problematike. $Z$ toho nám vyplýva, že táto téma zostávala $v$ odbornom diskurze od počiatkov vel'mi limitovaná, podobne ako je to aj v súčasnosti.

$\checkmark$ nasledujúcom texte sú vymedzené tri kategórie rôznych období a zariadení vzhl'adom na prípravu na vyučovanie, konkrétne na postavenie DÚ v danej režimovej činnosti. Pri vytváraní týchto návrhov boli brané do úvahy nasledujúce okruhy: (a) ciele a úlohy prípravy na vyučovanie; (b) obsah prípravy na vyučovanie; (c) časová dotácia prípravy na vyučovanie $v$ rámci režimu dňa.

\subsection{Detské útulky}

Koncom 19. a začiatkom 20. storočia sa začína na našom území (ešte v rámci Rakúsko-Uhorska) vel'ký rozvoj priemyselnej výroby. V mestách dochádza k prílivu obyvatel'stva $z$ chudobného vidieka, ktoré hladá v priemysle lepšie zárobky. Do zamestnania nastupujú aj ženy, ktoré mali byt' lacnou pracovnou silou, a preto majitelia priemyselných podnikov súhlasili s tým, aby sa zaradili do práce (Dedeková et al., 1960).Vynára sa tu čoraz väčšia potreba zabezpečit' starostlivost' o deti v čase, kým sú rodičia $v$ práci. $Z$ iniciatívy charitatívnych spolkov začali vznikat' prvé denné útulky pre deti. Najskôr sa zriad'ovali útulky len pre deti predškolského veku. Vychádzalo sa zo zásady, že diet’a, ktoré čast' svojho času strávi v škole, nepotrebuje až takú starostlivost', ako diet'a predškolského veku. Ale po prvej svetovej vojne sa začali ozývat' hlasy, ktoré žiadali útulky aj pre školopovinné deti (Dedeková et al., 1960).Útulky sa zriad'ovali hlavne vo väčších mestách a v priemyselných strediskách. Na Slovensku vznikol prvý útulok vo februári 1908 pri tabakovej továrni v Košiciach (Groch \& Valovič, 1963). Hlavným cielom bolo deti zamestnat' tak, aby sa nemohli venovat' nevhodným a pre deti škodlivým činnostiam. Pávková a kol. (2008) uvádzajú, že dôraz sa tu kládol na telovýchovu, turistiku, pracovnú výchovu, spoznávanie prírody a histórie regiónu, deti boli vedené k sebaobslužným činnostiam a vypracovávali si DÚ. Príprava na vyučovanie $v$ časoch útulkov tu bola chápaná v zmysle samostatného vypracovávania si DÚ, ktoré im boli neskôr kontrolované. Vypracovávanie Dú bolo zaradené v režime hned’ ako sa tzv. „chovanci“ stretli v útulku.

\subsection{Družiny mládeže}

Denné útulky boli v roku 1931 premenované na družiny mládeže. Boli zriad’ované ako sociálne a výchovné zariadenia, podporovali školskú výchovu a umožňovali tak matkám nástup do zamestnania. Možno povedat', že táto sociálna funkcia prevažovala nad tou výchovnou a vzdelávacou. Vo väčšom počte boli družiny mládeže zakladané po roku 1945 najmä v súvislosti so spoločenskými a ekonomickými zmenami. Školským zákonom z roku 1948 boli družiny mládeže začlenené do školskej sústavy ako mimoškolské zariadenia, neboli však súčast’ou škôl (Pávková a kol., 2008). „Od roku 1949 začalo podla potreby Povereníctvo práce a sociálnej starostlivosti zriad'ovat' 
pri národných a stredných školách siet' družín mládeže. Úlohou družín bolo starat' sa o deti pracujúcich matiek $v$ čase mimo vyučovania, poskytnút' im stravu a pobyt vo vhodných miestnostiach, kde by sa mohli pripravovat' na vyučovanie“ (Dedeková a kol., 1960, s. 8). Družiny mládeže tak vznikali v rámci jedného rezortu a môžeme tak vidiet' prepojenie takéhoto zariadenia so sociálnou politikou štátu.

Školské družiny nadväzovali na školskú výchovu. Cielom takejto výchovy bol podla Podešvu (1952) všestranný rozhl'ad. Podešva charakterizoval 5 zložiek výchovy, ktoré boli súčast’ou procesu plánovania činností v družinách mládeže (rozumová, pracovná a polytechnická, ideová a mravná, estetická a telesná výchova ${ }^{8}$ ). Vzhl'adom na cielové zameranie príspevku je pre nás dôležitá najmä rozumová výchova, ktorá mala dat' det'om/žiakom vedecké poznatky, rozvíjat' ich myslenie, pamät' a predstavivost'. Tu bolo úlohou družín mládeže aj odhal'ovat' pričiny prípadného neúspechu žiaka a vychovávat' ho $\mathrm{k}$ návykom učenia sa a vypracovávania DÚ.

Príprava na vyučovanie mala $v$ družinách mládeže dominantné postavanie oproti ostatným činnostiam, bola zarad'ovaná každý deň po oddychu. Náplňou tejto činnosti bolo písanie DÚ, preberanie novej látky a opakovanie. Vychovávatel'ka ${ }^{9}$ pri písaní DÚ pomáhala a usmerňovala deti. Aby vychovávatel'ka dokázala det’om s DÚ pomôct' a identifikovat' prípadné problémy s učením, musela ovládat' metodiku jednotlivých predmetov a ich obsah. Preto vychovávatel'ky chodili na hospitácie na vyučovanie a boli oboznamované s prospechom jednotlivých detí. Navyše, ak vychovávatel'ka spozorovala zhoršenie prospechu niektorého žiaka, musela podniknút' kroky k náprave vo forme opätovného/hlbšieho prebratia učiva so žiakom. Sám Podešva (1952) v príručke pre vychovávatel'ky píše, že nie je možné využivat' každé učivo preberané $\checkmark$ škole, preto by sa mala vychovávatel'ka vždy poradit' s učitel'mi, čo bude potrebné $v$ družine ešte viac rozviest'.

Samostatná príprava na vyučovanie trvala $80-90$ minút s jednou 5-10minútovou prestávkou, počas ktorej deti spievali alebo si zacvičili. Vychovávatel'ka mala deti naučit' ako sa správne pripravit' na vyučovanie. $V$ družinách mládeže tak deti získavali návyky a znalosti potrebné na samostatné učenie. DÚ si deti vypracovávali podla poradia, ktoré určila vychovávatel'ka. Najčastejšie si vypracovávali najskôr písomné úlohy a neskôr sa pristúpilo k ústnym. Vychovávatel'ka det’om Dú kontrolovala, no chyby neopravovala. Deti upozorňovala len na chyby z nepozornosti, ostatné prenechávala na kontrolu učitelovi. V príručke Podešvu (1952) je zaujímavé, že proces písania DÚ necháva výhradne v rukách vychovávatel'ky, dokonca nabáda, že ak sa ozvú rodičia a deti, ktoré si chcú písat' Dú doma, majú ich taktne presvedčit', že $\checkmark$ družine to bude lepšie. Prikladá sa vel'ká dôležitost' tomu, aby pri príprave na vyučovanie postupovala vychovávatel'ka rovnakými metódami ako učitelia, aby deti neboli zmätené. Odporúčajú sa však aj rôzne spestrenia, najmä didaktické hry na vzbudenie záujmu diet'at’a o nejaký predmet.

8 Uvedených 5 zložiek výchovy možno pokladat' za prekurzor tematických oblastí výchovy, s ktorými sa stretávame $v$ dnešnom ŠKD.

9 V tejto časti textu ustupujeme od neutrálnejšieho pomenovania vychovávatel', pretože $v$ pôvodom texte (Podešva, 1952) sa píše len o vychovávatel'kách. 
Od roku 1950 prešli družiny mládeže určitým vývojom. Spočiatku mali skôr sociálnu funkciu, neskôr sa zameriavali na výchovný rozmer. Takáto postupná premena viedla aj k tomu, že sa začali stanovovat' kritériá pre prijímanie detí do družín mládeže, takisto sa samozrejme mení aj samotný obsah práce s det'mi. Takýmto kritériom bola zamestnanost' matiek. Prijímali sa deti, ktorých matky pracovali a do popredia sa v práci s det'mi dostáva pomoc det’om pri učení. To dokazujú aj organizačný poriadok a prijaté smernice, ktoré v roku 1957 vydalo Povereníctvo školstva a kultúry, v ktorom sa piše, že „Družiny mládeže sú mimo školské výchovné zariadenia, ktoré sa starajú v čase mimovyučovacom a cez prázdniny o výchovu žiakov 1.-8. postupového ročníka všeobecno-vzdelávacích a osobitných škôl, predovšetkým o deti zamestnaných matiek" (cit. podla Dedeková et al., 1960, s. 9). V tomto čase je už badatel'ná značná podobnost' $k$ súčasným ŠKD, pretože družiny mládeže organizovali čas det'om tak, aby sa vo svojom volnom čase po skončení vyučovania zotavili pobytom na čerstvom vzduchu, hrami, športom, čítaním, technickými, výtvarnými a inými prácami podla vlastných záujmov. Starali sa tak o telesný vývin detí a v neposlednom rade u nich upevňovali hygienické a spoločenské návyky. Podla Dedekovej et al. (1960) bolo dôležitou úlohou družín mládeže zabezpečit' det’om vhodné podmienky pre riadnu a nerušenú prípravu na vyučovanie (práve príprave na vyučovanie sa venuje najväčšia pozornost'). Išlo najmä o deti robotníkov a rol'níkov, ktorým nevedeli alebo nemohli rodičia s prípravou na vyučovanie pomôct'. Hygienické a spoločenské návyky týchto detí sa rozvíjali najmä preto, že deti rol'níkov nevedeli napr. stolovat' a mali slabšie hygienické návyky.

\section{3 Školské družiny}

V školskom roku 1959/1960 nastala vo vývoji školských družín d’alšia zmena. Skúsenosti ukázali, že organizácia výchovnej práce v družinách, ktorá spočívala v spoločných aktivitách všetkých detí v oddelení, bez ohl'adu na vek, bola nevyhovujúca pre starších žiakov. V družinách bola prevaha mladších žiakov, ktorým sa vychovávatelia venovali prednostne a starší žiaci boli takpovediac „zanedbávaní“. Preto aj návštevnost' žiakov 6. -9. ročníkov v školských družinách bola nízka. Po tomto zistení vznikli pokusne $v$ školskom roku 1959/1960 asi na dvadsiatich školách kluby mládeže pre žiakov 6. -9. ročníka. Tieto zmeny vel'mi priaznivo ovplyvnili správanie a prospech žiakov. Na základe týchto zistení sa začali širšie zakladat' práve kluby mládeže (Groch \& Valovič, 1963). Zákon o sústave výchovy a vzdelávania č. 186 Zb., ktorý bol schválený vo vtedajšom Československu 15. decembra 1960, stanovil, že pre žiakov 1.-5. ročníka boli zriad'ované školské družiny, a pre žiakov 6.-9. ročníka školské kluby. Zákon taktiež stanovil, že školské družiny a školské kluby sa stali súčast'ou škôl: „Školy a výchovné zariadenia tvoria jednotnú školskú sústavu.“

Tým, že sa vytvoril samostatný priestor pre starších žiakov, zlepšili sa podmienky pre školské družiny, kde sa do jednej družinárskej triedy začali združovat' deti rovnakého veku, resp. postupového ročníka. Takáto družinárska trieda bola tak samostatným oddelením školskej družiny. Podobne sa vyjadrujú aj Groch a Valovič (1963), že 
vytvorenie takýchto tried ulahčovalo organizáciu výchovnej práce, teda aj samotnú prípravu na vyučovanie.

Z pedagogického i didaktického hladiska zdôrazňuje Opata (1980, s. 30) „úlohu výchovy mimo vyučovania v rozvoji samostatnosti a schopnosti sebavzdelávania“, ktorá sa uskutočňuje najmä v príprave na vyučovanie. Čas prípravy na vyučovanie sa pohybuje v rozmedzí od 45 minút po 1,5 hodiny, štyrikrát v týždni. Zdôrazňujú sa didaktické hry, doučovanie, konzultácia, či v staršom veku skupinová príprava na vyučovanie. V tomto prípade sa teda upúšt’a od drilu vypracovania Dú, ale ide skôr o upevňovanie a dopĺňanie prebratého učiva, avšak písomné vypracovanie Dú stále zostáva súčast'ou prípravy na vyučovanie. Tu sa začína zdôrazňovat' aj obsah výchovy mimo vyučovania v školských družinách a kluboch, ktorý je stále ideologicky a politicky ovplyvňovaný. Avšak výchovné činnosti v družine boli organizované tak, aby sa žiaci naučili aj odpočívat', dodržiavali sa zdravotno-hygienické zásady, rozvíjali sa ich záujmy. Oproti súčasným ŠKD boli v tomto období školská družina a školský klub bezplatné a $v$ prevádzke počas celého roka, okrem dní pracovného pokoja. Prednostne sa prijímali žiaci nižších ročníkov, ktorých rodičia pracovali (prihliadalo sa aj na d'alšie sociálne okolnosti).

Sociálna funkcia školskej družiny a školského klubu sa značne prelína s výchovno-vzdelávacou. Opata (1980) uvádza, že práve v príprave na vyučovanie sa najzretel'nejšie prejavujú sociálne rozdiely medzi žiakmi. Podla neho je to závislé od podmienok domácej prípravy žiakov a od rodičovskej či pedagogickej pomoci. Nevhodné domáce podmienky a sociálne prostredie žiakov má za dôsledok nedostatočný prospech, resp. zaostávanie žiakov (najčastejšie z robotníckych a rol'níckych rodín). Príprava na vyučovanie $v$ školských družinách a kluboch tak dostáva nový sociálny rozmer: „Vzhladom na rozdielne sociálne podmienky detí, domáca príprava sa stáva jedným z rozhodujúcich prostriedkov triednej diskriminácie“ (ibid., s. 120). Neprospech žiaka, s ním súvisiace Dú, či celá príprava na vyučovanie sa stávajú celospoločenským problémom. Preto sa družiny a kluby rozširujú nie len na deti zamestnaných rodičov, ale na všetky deti. Ak bola výchova vecou celej spoločnosti, bola aj príprava na vyučovanie vecou celej spoločnosti, nie len rodinného prostredia. Súčast’ou prípravy na vyučovanie boli aj tzv. predmetové krúžky. V rámci týchto krúžkov sa obsah viazal na učebné osnovy, no mal črty záujmovej činnosti. Boli určené pre deti, ktoré z nejakého dôvodu nezvládajú určitý predmet, ale aj pre deti, ktoré boli schopné učit' sa viac, teda nad rámec učebných osnov.

Podobne ako už v úvodných častiach spomínaní Corno a Xu (2004) sa vyjadruje aj Opata (1980). Corno a Xu (2004) videli prepojenie vypracovávania Dú s osobnostným rozvojom diet’at'a a manažérskymi či organizačnými schopnost'ami žiaducimi u súčasných zamestnávatelov. Opata (1980, s. 126) píše, že „d’alšou úlohou prípravy na vyučovanie je naučit' deti ekonomiku práce, umeniu rozvahy, premysliet' veci, projektovat’ postup práce“. Avšak jeho vyjadrenia nesmerujú k potrebám kapitalistického trhu práce a zamestnávatel'ov, ale k učeniu sa postupov, schopností a zručností potrebných pre spoločensky prospešnú prácu. Túto tendenciu zaznamenávame ešte v publikácii Miroslava Špánika (1990). Podla neho je úlohou výchovy mimo vyučovania 
„viest' mládež $\mathrm{k}$ všeobecne prospešnej práci... uplatňovat' vedomosti a skúsenosti v praktických životných situáciách“ (s. 7). Identifikoval 6 zložiek výchovy mimo vyučovania (rozumová, ekologicko-vlastenecká, mravná, estetická, pracovná a telovýchovno-branná), pričom najvyšší dôraz kladie práve na rozumovú výchovu. Tu upriamuje pozornost' na prehlbovanie poznatkov prostredníctvom riešenia praktických problémov a prepojenie rozumovej výchovy s učebnými osnovami. Školské družiny a kluby považuje za intencionálne výchovné prostredie a prípravu na vyučovanie pokladá (ešte stále) za nástroj odstraňovania sociálnych rozdielov medzi žiakmi.

\section{4 Školské kluby detí}

V roku 1993 bol Národnou radou SR schválený právny predpis, ktorým je zákon č. 279/1993 Z. z., o školských zariadeniach a o zmene a doplnení niektorých zákonov $\checkmark$ znení neskorších predpisov. Tento zákon ustanovil, že školský klub detí nahrádza školskú družinu a školský klub a týmto preberá ich funkciu $v$ doterajšom sociálnom a výchovnom poslaní. O výchovno-vzdelávacích zariadeniach, teda aj školských kluboch uvádza, že „utvárajú podmienky na hrovú, záujmovú a oddychovú činnost' detí. Pomáhajú pri ich príprave na vyučovanie a podiel'ajú sa na rozvíjaní ich nadania, špecifických schopností a tvorivosti“. V tomto období sa začalo intenzívnejšie pracovat' na odstraňovaní jednostranných ideologických myšlienok z obsahu výchovy a vzdelávania $v$ SR. Neskoršími novelizáciami sa mierne upravovala činnost' ŠKD až do súčasnej podoby, kde príprava na vyučovanie neustále tvorí súčast' výchovno-vzdelávacej činnosti. Príprava na vyučovanie bola zarad'ovaná do denného režimu po odpočinkových činnostiach štyrikrát do týždňa. Po roku 2009 majú ŠKD povinnost' vypracovávat' výchovný program a podla vzorového výchovného programu dostupného na stránkach Ministerstva školstva, vedy, výskumu a športu vychovávatelia zarad'ovat' prípravu na vyučovanie do vzdelávacej (rozumovej) tematickej oblasti výchovy. Cielovým zameraním tejto tematickej oblasti výchovy je práve rozvíjanie autonómnosti v príprave na vyučovanie, efektívne spôsoby učenia sa, získavanie nových poznatkov a informácií z rôznych zdrojov a budovanie vzt’ahu k celoživotnému učeniu sa. Dokument Tvorba výchovných programov v školských zariadeniach (2009) teda nesmeruje plánovanie výchovno-vzdelávacej činnosti priamo k vypracovávaniu si Dú v ŠKD. Prevláda skôr tendencia didaktických hier, vychádzok, diskusií a iných aktivít, ktoré smerujú $k$ upevňovaniu a prehlbovaniu poznatkov nadobudnutých v škole. Podla vzorovej ukážky výchovného plánu ŠKD v tomto dokumente je však vzdelávacej tematickej oblasti venované množstvo času. ${ }^{10}$ Zo šiestich tematických oblastí výchovy (vzdelávacia, spoločenskovedná, pracovno-technická, prírodovedno-environmentálna, estetickovýchovná a telovýchovná, zdravotná a športová) je vzdelávacej oblasti vymedzených 165 výchovno-vzdelávacích činností, pričom ostatné majú len 33. Vo výkonových štandardoch je len jednou čast'ou samostatné vypracovávanie si

10 Bližšie sa problematike stotožňovania výchovno-vzdelávacej činnosti prípravy na vyučovanie v ŠKD s písaním si DÚ venuje príspevok Bielikovej (2018). 
DÚ. Kompetencia vypracovávania DÚ sa tak po rokoch dostáva naspät' do rúk rodiča, ktorý by mal prevziat' zodpovednost' za výchovu a vzdelávanie svojich detí.

Preberanie zodpovednosti za výchovu a vzdelávanie svojich detí vidia Kaščák a Pupala (2012) ako neoliberalizáciu vzt’ahu medzi školou a rodinou. Ukazujú to na príklade príručiek pre rodičov, ktoré vydalo v USA Department of Education. Jednou z týchto príručiek je aj príručka domácej prípravy na školu (Helping your Child with Homework). Domácu prípravu autori považujú za „priestor pre extenziu školy do rodiny a prístupu rodiny do školského diania“ (s. 163). Rodičia tak prostredníctvom DÚ môžu kontrolovat' dianie v škole, na čo poukazujú aj Walker et al. (2004). Mnohé vychovávatel'ky nechajú deti samostatne si vypracovat' DÚ v ŠKD, ale kontrolu správnosti vypracovania ponechávajú na rodičoch. $V$ súčasnosti sa aj mnohí rodičia vyjadrujú, že nechcú, aby si diet’a v ŠKD vypracovávalo DÚ, preto je zaužívané, že ŠKD sa s rodičmi dohodnú, či si deti budú, alebo nebudú DÚ vypracovávat' v ŠKD. ŠKD sa tak stáva prechodným miestom, ktoré preberá funkcie školy i funkcie rodiny, avšak nie do takej miery, aby zasahoval do ich zaužívaných schém fungovania.

Ked'že písanie DÚ je vždy zarad'ované v režimovej činnosti prípravy na vyučovanie $\checkmark$ jednotlivých zariadeniach, zamerali sme sa na tri okruhy tejto režimovej činnosti: (a) ciele a úlohy prípravy na vyučovanie; (b) obsah prípravy na vyučovanie; (c) časovú dotáciu prípravy na vyučovanie $v$ rámci režimu dňa. Stručne a prehl'adne sú tieto okruhy zobrazené v nasledujúcej tabul'ke 1 .

Tabul'ka 1 Ciele, úlohy, obsah a časová dotácia prípravy na vyučovanie v jednotlivých zariadeniach

\begin{tabular}{|c|c|c|c|c|}
\hline & Útulky/opatrovne & Družiny mládeže & Školské družiny & Školské kluby detí \\
\hline $\begin{array}{l}\text { Ciele } \\
\text { a úlohy }\end{array}$ & $\begin{array}{l}\text { samostatne } \\
\text { vypracovat' } \\
\text { DÚ }\end{array}$ & $\begin{array}{l}\text { samostatne } \\
\text { vypracovat' } \\
\text { DÚ, prehlbovat' } \\
\text { všeobecné vzdelanie, } \\
\text { odhal'ovat' problémy } \\
\text { s učením }\end{array}$ & $\begin{array}{l}\text { samostatne vypraco- } \\
\text { vat' DÚ, opakovat', } \\
\text { precvičovat' } \\
\text { a utvrdzovat' } \\
\text { poznatky z vyučo- } \\
\text { vania }\end{array}$ & $\begin{array}{l}\text { viest' deti k pravi- } \\
\text { delnému plneniu si } \\
\text { povinností, prehlbo- } \\
\text { vaniu vedomostí, } \\
\text { učit' ako sa správne } \\
\text { učit', rozvíjat' vzt'ah } \\
\text { k celoživotnému } \\
\text { učeniu sa }\end{array}$ \\
\hline Obsah & $\begin{array}{l}\text { vypracovanie } \\
\text { úloh }\end{array}$ & $\begin{array}{l}\text { vypracovanie } \\
\text { úloh, prehlbovanie } \\
\text { vedomostí rôznymi } \\
\text { metódami a formami }\end{array}$ & $\begin{array}{l}\text { vypracovanie } \\
\text { úloh, prehlbovanie } \\
\text { vedomostí rôznymi } \\
\text { metódami a formami }\end{array}$ & $\begin{array}{l}\text { precvičovanie } \\
\text { a upevňovanie učiva } \\
\text { rôznymi formami } \\
\text { a metódami }\end{array}$ \\
\hline $\begin{array}{l}\text { Časová } \\
\text { dotácia }\end{array}$ & Neurčené & $80-90 \mathrm{~min}$ & $60 \mathrm{~min}$ & $45 \mathrm{~min}$ \\
\hline
\end{tabular}

\subsection{Postavenie domácich úloh v priebehu času}

Prostredníctvom štúdia dostupných zdrojov sme sa dopracovali k spôsobu realizácie DÚ v poškolských zariadeniach v postupnej časovej línii. Vzhladom na vyššie uvedený 
42 text sme vytvorili nasledujúce kategórie, ktoré svojim spôsobom slúžia ako určitá periodizácia vývinu činnosti (súčasnej) prípravy na vyučovanie. Pri vytváraní týchto kategórií sme vychádzali z okruhov uvedených v Tabul'ke 1 a nazerali sme na jednotlivé obdobia i poškolské zariadenia $v$ socioekonomickom kontexte. V tomto smere sa nám javí ako produktívne pre nasledujúci text neprihliadat' na historicko-politický kontext v takej miere, ako na socioekonomický, pretože načrtnutá periodizácia by sa nedala tak jednoznačne kategorizovat'. Prichádzame tak aj na odpoved', kedy sa Dú v poškolských zariadeniach objavuje a jednotlivé kategórie opisujú aj jej postavenie a čiastočne i význam. I ked' časová dotácia prípravy na vyučovanie postupne klesala, obsah činností sa $v$ jednotlivých zariadeniach rozširoval a stával sa viac pestrejším:

1) DÚ ako povinnost' - útulky a opatrovne;

2) DÚ ako (zdanlivá) možnost' vol'by - družiny mládeže a školské družiny;

3) DÚ ako služba - ŠKD.

\section{DÚ ako povinnost'}

Do tejto kategórie zarad'ujeme útulky a opatrovne. Deti ani rodičia nemali možnost' vyjadrit' sa k vypracovávaniu si Dú, pretože toto bolo prioritným cielom a jediným obsahom opatrovní a útulkov. V rámci celého denného režimu sa žiaci prioritne zameriavali na vypracovanie Dú a aj na ústne preskúšanie prípravy na vyučovanie. Do popredia tu vystupuje najmä charitatívno-sociálna funkcia, ked'že hlavnou úlohou útulkov bolo to, aby deti nestrávili čas po skončení vyučovania na ulici, ale aby dostali najest' a vypracovávali si Dú zadané v škole. Deti boli vedené k samostatnému vypracovávaniu si Dú a k samostatnej príprave na vyučovanie. Avšak, denné útulky sa zriad'ovali len $v$ malom počte (najmä vo väčších mestách v prítomnosti priemyselných podnikov) a neposkytovali starostlivost' det'om z rodín sociálne najslabších (Groch \& Valovič, 1963). Aj napriek venovaniu sa Dú a príprave na vyučovanie v širokom spektre, boli útulky zriad'ované najmä charitatívnymi organizáciami, a teda dominuje v tomto období práve sociálna funkcia útulkov nad vzdelávacou či socializačnou.

\section{DÚ ako (zdanlivá) možnost' vol'by}

Dominantnými reprezentantmi v tejto kategórii sú družiny mládeže a školské družiny. Možnost' vol'by vidíme v tom zmysle, že rodičia mohli rozhodnút' o tom, či si ich diet'a (ne)bude robit' DÚ v tomto zariadení. Avšak, ako sme už uvideli vyššie, úlohou vychovávatel'ky bolo taktne rodičov presvedčit', aby pristúpili k tomu, aby si ich diet'a robilo DÚ $v$ družinách mládeže. V tomto období sa rodičia (najmä robotníci a rol'níci) považovali za menej kompetentných v danej oblasti, ako samotní vychovávatelia. Tu možno vidiet' isté prepojenie s prvou kategóriou - aspoň zo strany vychovávatel'ov a učitelov, ktorí uprednostňovali DÚ ako povinnost', aj napriek tomu, že rodičia mali zdanlivú možnost' vol'by. V družinách mládeže pripomínala príprava na vyučovanie skôr doučovanie a domácu prípravu do školy. Úlohou vychovávateliek bolo zároveň identifikovat' prípadné problémy s učením a reflektovat' ich $v$ príprave na vyučovanie tak, aby sa predišlo prípadnému neprospechu žiaka. K tomu sa prispôsobovala aj činnost' vychovávatelov (sledovanie prospechu žiakov či ovládanie obsahu učiva 
preberaného v škole, metód a postupov triedneho učitel'a). Ciele a úlohy týchto zariadení smerovali k zlepšeniu školskej úspešnosti žiakov. Vzhladom na to, že príprava na vyučovanie sa realizovala ako forma doučovania, plnila predovšetkým výchovno-vzdelávaciu funkciu.

\section{Dú ako služba}

Táto kategória je reprezentovaná súčasnými ŠKD. Vypracovanie DÚ v ŠKD sa realizuje prioritne písomnou formou a upúšt'a sa aj od doučovania učiva, ktoré sa preberalo počas školského vyučovania. $V$ súčasnosti rodičia rozhodujú o tom, či si ich diet'a bude/nebude písat' DÚ v ŠKD v plnej miere (resp. sa prihliada na názor väčšiny rodičov). Avšak vychovávatelia už nemajú „povinnost”“ presviedčat' rodiča, aby si diet’a DÚ vypracovávalo v ŠKD, ba práve naopak, pri súčasnej vekovej skladbe detí v ŠKD možno predpokladat' zo strany vychovávatel'ov presný opak. Tu možno vidiet' najväčšiu zmenu v porovnaní s ostatnými zariadeniami - príprava na vyučovanie sa nerovná písaniu si Dú. Jej hlavnou náplňou sú rôzne didaktické hry, zamerané prevažne na slovenský jazyk a matematiku. I ked’ istým spôsobom si žiaci precvičujú preberané učivo (najmä zábavnou formou), upustilo sa od drilu prípravy na vyučovanie ako formy doučovania. Z toho dôvodu vnímame vypracovávanie DÚ v súčasných ŠKD ako istú formu služby ŠKD pre rodiča, ktorú môže, ale nemusí využit'. Môžeme povedat', že výchovno-vzdelávacia funkcia už nie je dominantou tejto režimovej činnosti, i ked' je stále jej súčast'ou. Celý režim dňa v ŠKD sa prispôsobuje biorytmu a individualite diet'at'a, čiže podlieha aj zdravotnej funkcii, resp. zdravotno-hygienickej funkcii (vid’ Kratochvílová, 2010, Pávková et al., 2008) a rovnako sa zdôrazňuje potreba socializácie diet'at'a a jeho tvorivosti a osobnostného rozvoja.

\section{Záver}

Pozriet' sa na Dú cez prizmu funkcií vol'ného času a poškolských programov sa na prvý pohl'ad javí nezmyselne. Vol'ný čas by mal byt' predsa časom bez povinností a Dú je vnímaná ako povinnost', čo možno označit' za špecifikum našich výchovno-vzdelávacích zariadení, ktoré organizujú vol'ný čas detí tak, aby ho trávili produktívne, organizovane a účelne. Môže to mat' vynikajúce efekty v nadväznosti na tol'ko spomínanú školskú úspešnost' našich detí. Príprava na vyučovanie ako výchovno-vzdelávacia činnost' nie je tak špecifická len $v$ našich ŠKD alebo v českých školních družinách a kluboch. Podobne zamerané poškolské programy existujú v zahraničí, najmä v USA. Ich ciele a poslanie, ktoré sme zhrnuli v úvodných slovách ako funkcie poškolských programov, možno označit' za vel'mi podobné s našimi zariadeniami. Tieto funkcie sa prelínajú v príprave na vyučovanie, aj vo vypracovávaní si Dú. Diet’a je vedené k samostatnosti, zodpovednosti a k systematickej príprave na vyučovanie, pričom je súčast’ou kolektívu a pod dozorom dospelej, kvalifikovanej osoby. Avšak, v USA sú tieto poškolské programy zriad'ované najmä ako sociálna služba v problémových komunitách, kde je potreba zvýšenia školskej úspešnosti detí a ich začlenenia sa 
44 do spoločnosti. U nás poskytuje ŠKD akýsi komplex služieb, ktorý sa orientuje na potreby a záujmy diet'at'a.

Jednou zo základných úloh prípravy na vyučovanie je zapojenie rodičov do školských povinností jeho diet'at’a. Zdá sa však, že tu existuje riziko nezapojenia rodičov do tohto procesu, ak si diet’a DÚ vypracováva v ŠKD. V súčasnosti je ale príprava na vyučovanie ovel'a širšou oblast'ou ako len písanie DÚ. A ked’že je ŠKD súčast’ou základnej školy, dohadujú sa rodičia s učitel'mi i vychovávatel'mi, či a ako si ich deti v ŠKD DÚ budú vypracovávat'. Vychovávatel' je v tomto procese pomocník, nekontroluje správnost' vypracovania DÚ, túto kompetenciu prenecháva rodičovi.

Dominantnou funkciou v našom príspevku bola sociálna funkcia. Často sa prelínala, a aj sa nad'alej prelína $v$ rôznych zdrojoch so socializačnou funkciou. Sociálna funkcia je však podobne chápaná v zahraničí i u nás. Poškolské programy, podobne ako ŠKD, sú vnímané ako služba zamestnaným rodičom. Najmä vd'aka zamestnanosti žien/matiek začali práve takéto zariadenia vznikat' a naberat' na popularite. V súčasnej situácii je takáto služba priam nevyhnutná. Často máme pracujúcich oboch rodičov, niekedy pracujú na zmeny a nemajú čas sa venovat' det’om, nie len v trávení ich volného času, ale aj v príprave na vyučovanie. Od konca 19.storočia tak vznikali podobné zariadenia vo svete, ktoré spočiatku „dohliadali“ na deti pracujúcich rodičov. Podobne ako napr. v USA či inde vo svete zakladali takéto poškolské zariadenia najmä charitatívne organizácie a neskôr sa k ním pridal aj súkromný sektor. Zatial' čo $\checkmark$ USA boli detské domy a podobné zariadenia vnímané ako miesto trávenia volného času tak, aby sa predchádzalo sociálno-patologickým javom, prvé detské útulky na našom území sa zameriavali na prípravu detí do školy a kontrolu Dú. Chovanci boli teda vedení $\mathrm{k}$ tomu, aby sa po príchode zo školy venovali Dú, a následne im ich kontrolovali. Nedbalo sa na akúsi výkonnostnú krivku, na oddych či rekreáciu. Tzn., že zdravotná funkcia sa nebrala vôbec do úvahy. V 30-tych rokoch boli tieto detské útulky premenované na družiny mládeže a začali sa orientovat' na podporu školskej výchovy, aj napriek tomu, že boli považované za sociálne zariadenia, výchova a vzdelávanie si tu začali vytvárat' väčšie miesto. Od roku 1948 boli družiny mládeže začlenené do školskej sústavy, avšak nemuseli byt' priamou súčast’ou škôl. ${ }^{11}$ Tu je rozdiel medzi slovenským (aj českým) prostredím a zahraničím. Najmä v USA sú poškolské programy zriad'ované často súkromným sektorom a charitatívnymi organizáciami, niekedy aj štátom. Avšak, priama nadväznost' a kontrola zo strany štátu nedosahuje takú mieru ako v našom vzdelávacom prostredí. Ako sme uvádzali, v USA majú rodičia možnost' vybrat' si program v nadväznosti na školské kurikulum alebo bez nadväznosti. Ak je však diet’a zapísané do ŠKD, vždy sú príprava na vyučovanie i spomínané školské zručnosti v nadväznosti na štátny a následne i na školský vzdelávací program.

11 Od 1. septembra 2017 musí byt' ŠKD súčast’ou základnej školy. Prechodné ustanovenia k úpravám účinným od 1. septembra 2017 - ak školský klub detí zriadený do 31 . augusta 2017 nie je súčast’ou základnej školy, zriad'ovatel' zabezpeči všetky úkony smerujúce k tomu, aby bol školský klub detí najneskôr od 1. septembra 2018 súčast’ou základnej školy, inak ministerstvo rozhodneo vyradení školského klubu detí zo siete. 
Od vyššie spomínaného obdobia až po 90-te roky bola výchova a vzdelávanie $v$ družinách mládeže, neskôr $v$ školských družinách a školských kluboch, ideologicky podfarbená, čo sa prekvapivo ukazuje aj v problematike vypracovávania si Dú a v celkovej príprave na vyučovanie. $V$ príručkách pre vychovávatel'ky nachádzame dominantu sociálnej funkcie a jej konkrétne prepojenie s politikou a ideou štátu. DÚ a príprava na vyučovanie mali byt' rozhodne $v$ kompetencii školskej družiny alebo školského klubu. Ak by rodičia alebo deti chceli, aby si vypracovávali DÚ v domácom prostredí, boli vychovávatel'ky nabádané „odhovorit““ ich od toho. Vypracovanie DÚ pod dohl'adom vychovávatel'ky, ktorá úzko spolupracovala s učitel'mi, bolo vnímané ako pomoc. Bolo nevyhnutné znížit' počet žiakov, ktorí neprospievali v škole. Nebola to len pomoc, bolo to vnímané ako „prostriedok bojovania s triednou diskrimináciou“. Príprava na vyučovanie trvala aj viac ako hodinu a pol, pričom diet’a pokračovalo $v$ príprave na vyučovanie aj v domácom prostredí. Aby bola príprava na vyučovanie účelnejšia, začiatkom 60-tych rokov sa zriadili školské družiny a pre starších žiakov školské kluby. Školské kluby sa v tom čase nevenovali záujmom diet’at’a, diet’a tu zostáva žiakom a v študovni či iných odborných miestnostiach sa pripravovalo na vyučovanie, resp. chodilo na doučovanie. Neskôr, v 80-tych rokoch sa školské družiny a školské kluby nezameriavajú len na deti zamestnaných rodičov, ale na všetky deti. Školská pripravenost' a samostatnost' deti pri vypracovaní Dú získavali na dôležitosti. Sociálna a výchovno-vzdelávacia funkcia tak idú desat'ročia ruka v ruke naplńajúc i ideologické zámery štátu. Oddych a rekreácia detí boli síce súčast'ou režimu dňa, avšak aktívny oddych mal podporit' následnú mentálnu činnost' detí.

Konkrétnejšie uvol'nenie obsahu činností zaznamenávame od vzniku samostatnej SR v roku 1993 a od vzniku školského klubu detí, ktorý prebral činnosti školskej družiny i školského klubu. Rétorika zákona a smerníc sa mení, zdôrazňujú sa záujmy detí, rozvíjanie nadania, tvorivosti a pod., t. j. zdôrazňujú najmä humanistickú filozofiu. Súčast’ou samozrejme zostáva aj príprava na vyučovanie, ktorá sa výrazne skracuje v časovej dotácii, ale mení sa aj charakter samotných činností. Od roku 2009 zaznamenávame $v$ ukážkach tvorby výchovných programov pre ŠKD prípravu na vyučovanie, ktorej len malou súčast’ou je vypracovávanie si Dú. Viac je táto výchovno-vzdelávacia činnost' orientovaná na hry, diskusie, vychádzky a pod., ktoré majú doplnit' alebo prehíbit' vedomosti nadobudnuté počas vyučovania. Zdôrazňuje sa potreba oddychu, sebarealizácie a pod. Je zaujímavé sledovat', ako sa Dú detí prelínajú v premenách času raz s domácim, raz so školským prostredím, ako sa stávajú celospoločenským problémom nesúcim ideologický odkaz. Dnes sa síce vo vel'kej miere orientuje spoločnost' na školskú úspešnost' detí, ktorá je ale determinovaná kvalitou vzdelávania $v$ školách a mierou participácie rodičov. $V$ ŠKD sa v súčasnosti prelínajú všetky $v$ úvode spomínané funkcie takýchto poškolských zariadení. Dominantná zostáva sociálna funkcia, ktorej obsah sa však neorientuje na korektnú prípravu na vyučovanie pod dohl'adom kvalifikovanej osoby, ale na bezpečnost' a aktívne trávenie vol'ného času detí, kým sú rodičia v práci.

Ak sa pozrieme na výchovné programy ŠKD v súčasnosti, vypracovanie DÚ je chápané ako možnost'. Príprava na vyučovanie je orientovaná na variabilitu metód 
46 a foriem práce s det’mi, ktoré sa v súčasnej podobe naozaj dajú vnímat' ako trávenie vol'ného času. Vychovávatel'ky sa zameriavajú najmä na zaujímavosti a zábavnú formu činností spojených s prípravou na vyučovanie. Súčasné tendencie tak nechávajú žiakovi priestor zostat' diet'at’om participujúcim v kolektíve s rovesníkmi. Domáca úloha a príprava na vyučovanie sa stávajú „domácimi“, minimálne v rovine prenechávania rodičovskej zodpovednosti za kontrolu vypracovania.

\section{Literatúra}

Adams, G., Tout, M. , \& Zaslow, K. (2007). Early care and education for children in low-income families: Patterns of use, quality, and potential policy implications. Dostupné z https:// www.urban.org/research/publication/early-care-and-education-children-low-income-families

Beck, E. L. (1999). Prevention and intervention programming: Lessons from an after-school program. Urban Review, 31(1), 107-124.

Bieliková, M. (2018). Analýza výchovných programov školských klubov detí. Pedagogika.sk, 9(3), 135-149.

Corno, L., \& Xu, J. (2004). Homework as the job of childhood. Theory Into Practice, 43(3), 227-233.

Cosden, M., Morrison, L., Albanese, A. L., \& Macias, S. (2001). When homework is not homework: After-school programs for homework assistance. Educational psychologist, 36(3), 211-221.

Cosden, M., Morrison, G., Gutierrez, L., \& Brown, M. (2004). The effects of homework programs and after-school activities on school success. Theory into Practice, 43(3), 220-226.

Dedeková, N., Vaňková, I., Macko, A., \& Mesiar, A. (1960). Niektoré výchovno-vzdelávacie otázky $v$ družinách mládeže. Bratislava: Slovenské pedagogické nakladatel'stvo.

Epstein, J. L. (1988). Homework practices, achievements, and behaviors of elementary school students. (Research report). Dostupné z https://files.eric.ed.gov/fulltext/ED301322.pdf

Eren, O., \& Henderson, D. J. (2011). Are we wasting our children's time by giving them more homework? Economics of Education Review, 30(5), 950-961.

Groch, J., \& Valovič, Š. (1963). Hygiena školských družín. Martin: Osveta.

Hájek, B., Hofbauer, B., \& Pávková, J. (2008). Pedagogické ovlivňování volného času. Praha: Portál.

Halpern, R. (1992). The role of after-school programs in the lives of inner-city children: A study of the "Urban Youth Network". Child Welfare: Journal of Policy, Practice, and Program, 71(3), 215-230.

Chen, Ch., \& Stevenson, H. W. (1989). Homework: A cross-cultural examination. Child Development, 60(3), 551-561.

Cho, J., \& Huang, D. (2009). Academic enrichment in high functioning homework afterschool programs. Journal of Research in Childhood Education, 23(3), 382-392.

Johnson, T. S., \& McComb, E. M. (2008). Homework help in afterschool programs: Literature review. Dostupné z http://www.sedl.org/afterschool/toolkits/homework/pdf/hw_lit_rev .pdf

Johnston, A. L. (2011). Implementing an afterschool intervention program at Castle Rock Middle School in seventh grade science and other core classes [Dizertačná práca]. Montana State Univesity: Montana.

Kaščák, O. \& Pupala, B. (2012). Škola zlatých golierov: vzdelávanie v ére neoliberalismu. Praha: Sociologické nakladatelství.

Kratochvílová, E. (2010). Pedagogika vol'ného času: výchova $v$ čase mimo vyučovania $v$ pedagogickej teórii a praxi. Trnava: Typi Universitatis Tyrnaviensis. 
Mahoney, J. L., Parente, M. E., \& Zigler, E. F. (2009). Afterschool programs in America: Origins, growth, popularity, and politics. Journal of Youth Development, 4(3), 23-42.

Minárechová, M. \& Bánovčanová, Z. (2016). Komparácia slovenských a českých školských klubov (družín) s vybranými krajinami. Pedagogická orientace, 26(2), 228-251.

MŠMT ČR (2002). Metodický pokyn k postavení, organizaci a činnosti školních družin.. (2002). Dostupné z http://www.msmt.cz/mladez/metodicky-pokyn-k-postaveni-organizaci-a -cinnosti-skolnich-druzin

Mullan, K. (2012). School's out - after-school's in: Children's after-school care arrangements and activities. In G. Daraganova, B. Maguire, J. Kaspar, \& B. Edwards (Eds.), The longitudinal study of Australian children: Annual statistical report 2012. Dostupné z https: / /data .growingupinaustralia.gov.au/pubs/asr/2012/ch6asr2012.pdf

Noam, G. G., Biancarosa, G., \& Dechausay, N. (2002). Learning beyond school: Developing the field of afterschool education. Cambridge: Harvard Graduate School of Education.

Opata, R. (1980). Teória a prax mimotriednej výchovy. Bratislava: SPN.

Pávková, J., Hájek, B., Hofbauer, B., Hrdličková, V., \& Pavlíková, A. (2008). Pedagogika volného času: teorie, praxe a perspektivy výchovy mimo vyučovaní a zařízení volného času. Praha: Portál.

Podešva, B. (1952). Práca v družinách mládeže: príručka pre vychovávatel'ky. Bratislava: Štátne nakladatel'stvo.

Posner, J. K., \& Vandell, D. L. (1999). After-school activities and the development of low-income urban children: A longitudinal study. Developmental Psychology, 35(3), 868-879.

Sarampote, N., Bassett, H. H., \& Winsler, A. (2004). Afterschool care: Child outcomes and recommendation for research and policy. Child Youth Care Forum, 33(5), 329-348.

Špánik, M. (1990). Výchova mimo vyučovania. Bratislava: Univerzita Komenského Bratislava.

Tvorba výchovných programov v školských zariadeniach (ukážka) (2009). Bratislava: SPÚ. Dostupné z https://www.minedu.sk/data/att/4107.pdf

Walker, J. M. T., Hoover-Dempsey, K. V., Whetsel, D. R, \& Green, Ch. L. (2004). Parental involvement in homework: A review of current research and its implications for teachers, afterschool program staff, and parent leaders. Dostupné z http://www.gse.harvard.edu /hfrp/projects/fine/resources/research/homework.html

Zákon Národnej rady Slovenskej Republiky 279/1993, o školských zariadeniach.

Zákon 186/1960 Zb., o sústave výchovy a vzdelávania.

Mgr. Zuzana Bánovčanová, PhD. katedra školskej pedagogiky Pedagogická fakulta, Trnavská univerzita

Priemyselná 4

91843 Trnava, Slovensko zuzana.banovcanova@truni.sk

Mgr. Michaela Bieliková, PhD. katedra školskej pedagogiky

Pedagogická fakulta, Trnavská univerzita Priemyselná 4

91843 Trnava, Slovensko michaela.bielikova@truni.sk 